\title{
The Portrait of Students' Mental Modelling Ability on the Concept of Kinetic Theory of Gases in Science Literacy
}

\author{
Hasnawati Haili1,* \\ ${ }^{1}$ Physics Education, MAN 1 Muna, Indonesia \\ *Corresponding author. Email: ojja.japila@gmail.com
}

\begin{abstract}
Before learning, students have already had initial knowledge about a concept called a mental model in terms of cognitive psychology. A static or dynamic review of the mental model that has been built and the extent to which individuals use mental model and conceptual frameworks to solve problems is called Mental Modelling Ability (MMA). Through this study, students' MMA related to the concept of the kinetic theory of gases will be identified. The method of the study was a qualitative method with data collection instruments in the form of tests and non-tests (interviews). The triangulation (combined) was done with qualitative analysis. The sample of this study was 30 students of class XI determined by the purposive method. The instrument used had been passed through a validity test of Pearson moment product correlation (bivariate Pearson) and a reliability test using the Alpha method. After triangulation was conducted, it was leveled. The results showed that $30 \%$ of students were still at the low MMA level, $50 \%$ were at the medium MMA level, and 20\% were at the high MMA level. The implications of this research's results indicated the role of mental models and mental modeling abilities in the knowledge construction process.
\end{abstract}

Keywords: Mental models, Mental modeling ability, Kinetic theory of gases, Science literacy.

\section{INTRODUCTION}

In recent years, students' interest in science has begun to decline. It is marked by the decline of mathematics and sciences learning achievement from 2015 to 2018 in a very significant decrease [1]. As part of science, students consider physics as a difficult subject [2]. Such an attitude makes students demotivated to further study physics [3]. Many studies have been conducted to unravel the causes of the low interest, attitude, motivation, and learning outcomes of physics. One of the most dominant factors influencing the process and outcomes of students' science learning is the conceptual change factor related to students' personal reasoning abilities [4]. The personal reasoning ability of students is in accordance with the principle of constructivism, which states that every student has prior knowledge gained from life experience. In the learning process, students will recall the initial knowledge and construct it into new knowledge [5], corresponding to the concepts and learning contexts they experience [6]. The formulation of how students understand, learn, and think is called a mental pattern or mental model.

Mental models play an essential role in individual and organizational learning [7]. Researchers of physics education have understood the importance of identifying the elements of students' physics knowledge in different physics contexts [8]. Investigating the structure of knowledge in various physics concepts provides many opportunities for researchers to discover general processes of how students understand, think, and use concepts in their function to understand, explain and predict the behavior of the physical world. One of the ways in detecting the mental model of students is to present problems to be solved. By solving problems, students can be stimulated to develop their thinking skills creatively and comprehensively. Before receiving formal learning experiences in the class, students have already had their own visualization and understanding of events or natural phenomena encountered in their daily environment and even have developed them independently [9]. Sirhan suggested the importance of 
clarifying or correcting concepts that already exist in long-term memory by conducting basic learning before adding new learning experiences because many students come into the class with the wrong, confusing, and even incomplete ideas [10]. It shows that the analysis of the mental model is an important study considering that the cognitive constructs formed will create a network of understanding and are stored in the long-term memory. In addition, knowing the mental model of a concept can reduce the level of difficulty in the learning process [11].

The overall structure of knowledge that exists in individuals is not only limited to the formation of the mental model but also the ability to build the mental model, use the mental model in solving problems, to the process of adding or changing the mental model through the process of metacognition. This ability is called Mental Modelling Ability (MMA). MMA reviews the static or dynamic nature of the mental model which have been constructed and the extent to which individuals use mental models and conceptual frameworks to solve problems [12]. Further, Wang states that the visualization of a mental model based on existing information and knowledge is a type of interaction between content knowledge and the ability to construct a mental model (MMA).

The ability to build mental models can be observed in the construction of knowledge about the essential concepts of physics. As a study that is close to human life, physics is a lesson that consists of a collection of knowledge or facts that must be memorized and an activity or an active process of using knowledge in studying natural phenomena and products. Accordingly, it is very possible if students have already had initial knowledge. The concept used in this study is the kinetic theory of gases, an abstract concept in which its symptoms cannot be observed directly. This allows students to have diverse knowledge in solving problems related to the material. The application of the material is also quite a lot so that it can invite students to give reasons and concepts they have. Based on this, it is necessary to conduct research to identify the students' mental modeling ability (MMA) on the concept of kinetic theory of gases. This study fulfills the element of novelty since there are only a few pieces of research about MMA identification. Though there are many mental model studies in several science concepts, few studies about students' MMA identification in physics essential concepts.

\section{METHODS}

The method used in this study was qualitative. It is a study investigating relationships, situations, or materials [13]. The population in this study were all students of class XI in the Mathematics and Natural Sciences specialization group at the State Madrasah Aliyah, an Islamic School, in Muna Regency. The sample is class XI Mathematics and Natural Sciences students taken by purposive technique. Data collection instruments in the form of tests and non-tests (interviews). The test instrument consists of five numbers essay questions in the form of problem-solving tests related to the concept of the kinetic theory of gases. The details are Boyle's Law, Charles' Law, Gay-Lussac's Law, Ideal Gas Equations, Kinetic Theory of Gases, and Principles of Energy Equipartition. Prior to the validity test in the form of Pearson's moment product correlation (bivariate Pearson), the test instrument used was firstly tested for content validity by experts involving three teachers/lecturers. Then, the reliability test was done using the Alpha method to test the feasibility of its use. The non-test instrument was in the form of an interview guide containing fifteen lists of questions that were used to clarify the results of the test instrument.

The data collection technique used in this study was triangulation between the results of the problem-solving test and the results of the interviews that have been conducted. Data analysis is inductive by displaying test results and interview results, and then they were analyzed qualitatively. The MMA indicator consists of 4 points, as summarized in Table 1. Points (a) and (b) are analyzed using the answer sheet, while points (c) and (d) are determined through the interview method. Then the leveling is done by calculating the number of scores obtained, where $0 \leq \mathrm{x} \leq 3$ is categorized as Low MMA, 3 $<\mathrm{x} 7$ is categorized as Medium MMA, and $7<\mathrm{x} 10$ is categorized as High MMA [14].

The MMA aspects studied refers to the categories and schemes of the MMA problem solver [15] were as follows: 
Table 1. Schemes of MMA problem solver

\begin{tabular}{|c|c|c|}
\hline No. & $\begin{array}{l}\text { The } \\
\text { categories of } \\
\text { MMA }\end{array}$ & The schemes of MMA problem solver \\
\hline 1 & $\begin{array}{l}\text { High Mental } \\
\text { Modelling } \\
\text { Ability } \\
\text { (HMMA) }\end{array}$ & $\begin{array}{l}\text { a. Generate mental model in the form of diagrammatic representations or other } \\
\text { relevant forms of representation. (Point 3) } \\
\text { b. Can reconstruct, manipulate or adjust mental model based on propositions or } \\
\text { problem conditions in the model. (Point 2) } \\
\text { c. Can restructure his approach to problems and constantly monitor the process of } \\
\text { explaining and constructing mental model. (Point 2) } \\
\text { d. Check and match the mental model and answer using an alternative approach if } \\
\text { the problem is relatively new. (Point 3) }\end{array}$ \\
\hline 2 & $\begin{array}{l}\text { Moderate } \\
\text { Mental } \\
\text { Modelling } \\
\text { Ability } \\
\text { (MMMA) }\end{array}$ & $\begin{array}{l}\text { a. Generate mental model based on diagrammatic representations or other relevant } \\
\text { forms of representation. If the problem is a known thing, they form a mental model } \\
\text { without looking at the representation (Point 3) } \\
\text { b. Has little ability to manipulate mental model when compared to HMMA students, } \\
\text { but at times, does not examine problems and the solution process carefully. } \\
\text { Therefore, they maintain their mental model instead of modifying or adapting it } \\
\text { based on new conditions in the problem (Point 1) } \\
\text { c. Monitor the mental modeling process on a limited basis or does not monitor } \\
\text { (Point 1) } \\
\text { d. Check the mental model and answer using an alternative approach is not real } \\
\text { (Point 2) }\end{array}$ \\
\hline 3 & $\begin{array}{l}\text { Low Mental } \\
\text { Modelling } \\
\text { Ability } \\
\text { (MMMA) }\end{array}$ & $\begin{array}{l}\text { a. Reconstruct the mental model based on memories of previous examples. It Often } \\
\text { does not form the mental model (point } 1 \text { or point } 0 \text { ) } \\
\text { b. Prefer pictures as a thinking tool then use propositions or problem conditions to } \\
\text { conclude (Point } 1 \text { ) } \\
\text { c. Does not monitor the mental model process (Point } 0 \text { ) } \\
\text { d. At the end of the conclusion or explanation, does not conduct a self-check to test } \\
\text { or examine the mental model or use the relevant representation as an alternative } \\
\text { approach (Points } 0 \text { or } 1 \text { ) }\end{array}$ \\
\hline
\end{tabular}

\section{RESULTS AND DISCUSSION}

Taken from the results of the study, the percentage of the MMA level of the students was obtained. The identification of the MMA level is carried out based on the analysis of the test answer sheet documents for points (a) and (b), as well as interviews to determine the leveling in points (c) and (d). The results of both are then categorized and summarized in the following table:
Table 2. Result of MMA leveling categorization

\begin{tabular}{|c|c|}
\hline Category & $\begin{array}{c}\text { Percentage MMA (\%) } \\
\text { Final Test }\end{array}$ \\
\hline LMMA & 30.81 \\
\hline MMMA & 47.62 \\
\hline HMMA & 21.57 \\
\hline Total & 100 \\
\hline
\end{tabular}




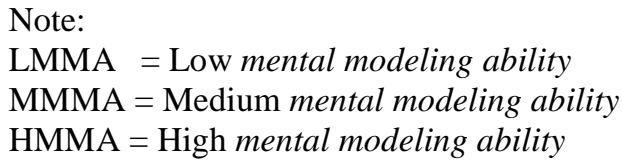

In the following, the mechanism for determining students' MMA, which uses a question to the students to show their MMA, is presented.

A question is given: In a car tire filling station, there are 3 types of tire pumps, with different types of gases, they are oxygen, nitrogen, and carbon dioxide. The performance of a tire is influenced by the high rate of increase in tire pressure due to changes in air temperature. The lower the increase in gas pressure, the better the tire performance will be. If all three pumps are used to fill a car tire that will be used under the same conditions (the tire volume, pressure, and outside air temperature are the same), then which gas-filled tire has the best performance?

Figure 1 below is one of the students' answers to the question above, which is given the initials S19.

The gas i use to fill car tires
is gas that comes from natural arr.
Why is that? Because if us Nitrogen
then the gas filled the car tires
is too low pressure, so it can't produse
good guality tires. Because the
content in Nitrogen is to stroug
when filled in tires. Therefore
natural air can provide guod
quality to tires

Figure 1 The answer of students S19.

From the answers given, it appears that students have not produced mental models yet in either diagrammatic representations or other relevant forms of representation. Students are not able to manipulate the mental model they have and do not have a proposed design (proposition) to solve the problem. As seen on the answer sheet, S19 stated that the answer was based on instinct alone. To confirm the results obtained on the answer sheet, the following are excerpts from the researcher's interview with S19.

$\mathrm{R}$ : After you read question number 5, what do you think?

S19 : I have to choose, Ma'am; do you want to use nitrogen or regular air for tires?

$\mathrm{R}$ : Have you thought of a solution?

S19 : When I was working on it, Ma'am, I was still thinking about how to do it.
$\mathrm{R}$ : Have you ever had an experience with tire gas filling?

S19 : Never, Ma'am, I only often hear about it because it is trending filling motorcycle and car tires with nitrogen.

$\mathrm{R}$ : So, what concept can be applied to choose the gas?

S19 : I don't know for sure, Ma'am, but I think it's because of a pressure

$\mathrm{R} \quad$ : Do you think so?

S19 : Yes, Ma’am.

$\mathrm{R}$ : So, in choosing gas, is there any relation between car or motorcycle tires and the pressure?

S19: Yes, Ma’am.

$\mathrm{R}$ : Please explain what is the relation?

S19 : If you use nitrogen, the gas pressure is too low so that the quality of the tires is not good

$\mathrm{R}$ : How do you know if the nitrogen gas pressure is low?

S19 : When we studied, it was mentioned that it had a relation with the molecular mass, Ma'am, but I forgot how it was explained.

$\mathrm{R}$ : Are you sure about this answer?

S19 : I'm not sure Ma'am, maybe nitrogen is better to use

R : Why?

S19 : maybe because the pressure is low,

$\mathrm{R}$ : If the pressure is low, what do you think is the relation with the tires?

S19 : If the pressure is right, the quality of the tires can be good, Ma'am.

$\mathrm{R}$ : If the amount of gas put into the tires is different between nitrogen and regular air, would you like to use nitrogen?

S19 : I don't know for sure, Ma'am,

$\mathrm{R}$ : If so, if the amount of gas put into the tires is different between nitrogen and regular air, Do you think the pressure is different?

S19 : I don't know, Ma'am.

$\mathrm{P}$ : So, that's all of the explanation or is there another solution? 
S19: That's all, Ma'am,

$\mathrm{R} \quad$ : Is your answer correct?

S19 : I don't know, Ma'am, but that's all.

$\mathrm{R} \quad$ : Don't you check again for sure?

\section{S19 : No, Ma’am.}

Based on the answer sheets and the results of the interview with students S19 on the kinetic theory of gases, it showed that $\mathrm{S} 19$ produced a mental model based on verbal representations relevant to the context of the question, which is about the pressure (Point 3 ). However, $\mathrm{S} 19$ had a rigid mental model and could not change his mental model when a new proposition was given to his mental model. S19 did not monitor metacognitively the process of preparing mental models. In addition, S19 tended to write as an instinct and did not conduct selfchecking using other approaches to test or examine mental models in identifying errors from the model. Based on this analysis, S19 got 3 points for his score, and it was in the LMMA category.

Referring to the MMA problem-solving scheme in the LMMA category, students with the LMMA category will usually reconstruct their mental model based on previous examples, use propositions or problem conditions to conclude, and do not monitor or even re-check the conclusion or explanation. These three characteristics occurred in the case of student S19. Thus, S19 was categorized based on the value and characteristics at the level of the LMMA.

Then, a question is given: In a physics competition for all students over Indonesia, you are selected to represent your district. You are faced with several challenges to complete the series of events. You get the first challenge to pop 1 balloon out of 3 available balloons. The three balloons contain a piece of paper containing instructions, while the other two are blank. There are three criteria for balloons that you can choose from. The criteria were as follow:

Balloon 1: The type of gas is Nitrogen and $30 \%$ of maximum size;

Balloon 2: The type of gas is Neon and $50 \%$ of maximum size;

Balloon 3: The type of gas is Hydrogen, and $80 \%$ of the maximum size

In this case, the maximum size of the balloon indicates the maximum numbers of molecules are $x$. The clue card is put inside the balloon with the highest internal energy, assuming that the size of the balloon and the gas temperature in the balloon is the same. Choose the balloon criteria which can help you win the challenge! Please, give the reason!

The following is one of the students' answers to the question above, which is given the initials S8.

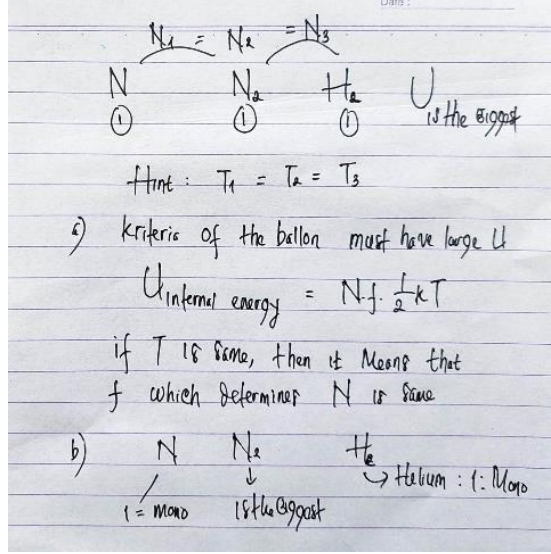

Figure 2 The answer of Students S8.

From the answers given, it appeared that the student had produced mental models in either diagrammatic representations or other relevant forms of representation (point 3). The student could not manipulate their mental model when given a new design to solve the problem. To confirm the results obtained on the answer sheet, the following are quoted from the researcher's interview with student S8.

$\mathrm{R}$ : After you read this question, what do you think?

S8 : I have to choose Ma'am, choose a balloon which has a clue card inside.

R : Have you thought of a solution?

S8 : Yes, I have already, Ma'am.

$\mathrm{R}$ : What is the solution?

S8 : In the question was told that the card containing the clue was in the balloon which had the most internal energy

$\mathrm{R}$ : What were you written first? Is it a picture?

S8 : Yes, Ma'am, in order to make it easy to understand, I draw it

$\mathrm{R} \quad$ : So, what was next?

S8 : Then, I was looking for which balloon had the highest internal energy?

$\mathrm{R}$ : How did you find it?

S8 : There is a formula to find out the internal energy, as I wrote (while pointing to the answer sheet) 
$\mathrm{R} \quad$ : Can you explain?

S8 : Yes, Ma'am, start to explain the answer

$\mathrm{R}$ : What is $\mathrm{f}$ that you wrote?

S8 : Degrees of freedom, if I'm not mistaken, Ma'am.

$\mathrm{R}$ : It means that the level of freedom has a role?

S8 : Yes Ma’am

$\mathrm{R}$ : Do you think this is the right solution?

S8 : Yes, Ma'am, because only the degrees of freedom are looking for

$\mathrm{R} \quad$ : Then, how about point $\mathrm{b}$ ?

S8 : Because each one is monoatomic, that's why I choose Ne.

$\mathrm{R} \quad$ : Why do you say monoatomic?

S8 : Because everything is single, Ma'am

$\mathrm{R}$ : If all are single, why do you choose Ne?

S8 : I think Ne is not a single, Ma'am.

$\mathrm{R} \quad$ : You say it was single at last.

S8 : I mean others except for Ne, Ma'am. Because He seems to be element of no. 1

$\mathrm{P} \quad$ : Is there any relation with elements?

S8 : Yes, Ma'am.

$\mathrm{R}$ : Can you explain the relation?

S8 : I forgot, Ma'am, but there's the relation definitely.

$\mathrm{R}$ : What do you think if the number of particles in each balloon is different? Does it still affect only the degrees of freedom of each balloon?

S8 : Yes, Ma'am, it can affect.

$\mathrm{R} \quad$ : Ok. Do you have any other solutions?

S8 : That's all I can think of, Ma'am.

$\mathrm{R} \quad$ : Is your answer correct?

S8 : I hope so, Ma'am.

$\mathrm{R}$ : Do not you check anymore?

S8 : I have checked it, Ma'am. I've looked once before I collect it.

Based on the answer sheets and the results of interviews with student S8 on the principle of energy equipartition, it showed that $\mathrm{S} 8$ produced a mental model in a diagrammatic representation which is relevant to the context of the question to facilitate its understanding (point 3). However, S8 has a rigid mental model and concluded that the shape of its mental model could not be changed when it was given a new proposition. S8 did not seem to be monitoring the process of preparing the mental model metacognitively. However, she was still doing self-checking by re-examining the use of the mental model to identify errors from the model (point 3 ). Based on this analysis, S8 got 6 points for her score, which was in the MMMA category.

Referring to the MMA problem-solving scheme in the MMMA category, students with the MMMA category will usually produce a mental model based on diagrammatic representations or other relevant forms of representation, have little ability to manipulate their mental model when it is compared to HMMA students but sometimes do not examine problems and the resolution process carefully. Therefore, they maintain their mental model rather than modify or adapt it based on new conditions in the problem. They do a limited to no monitoring at all and check the mental models even though they answer with alternative approaches, which is not real. Three of these four characteristics occur in student S8. Therefore, S8 is categorized MMMA based on its value and characteristics.

From the results of the interview conducted with students, it can be seen that the teacher's role in asking questions determines changes in students' thinking schemes. This is in line with the previous research finding that most students enjoy learning physics because of the teacher's factor, which continues to encourage students to correct their thinking on problems in physics [2]. In addition, the learning process should be able to trigger and increase students' involvement to solve problems coherently [16]. Both of these processes can be facilitated by revealing the mental model and the ability to change the mental model through the identification of Mental Model Ability (MMA).

As one of the things that affect students' learning outcomes [17], students' self-confidence can be helped through interviews to see their mental models and their ability to modify their mental models. Learning should allow students to develop their self-concept and relate it to the situations they face [18]. So, it is very important to carry out learning which fosters students' attitudes, motivation, and discipline in learning [19]. This series of processes can be facilitated through the identification of mental models and the ability to develop mental models, which is called as Mental Modeling Ability (MMA).

This research only studies students' MMA identification in the kinetic theory of gases, in which the scope of this study is only limited to its concepts. It is 
necessarily to continue this study to any further side to identify students' MMA in other essential physics concepts. This research can be used as a reference for other teachers and researchers in studying the kinetic theory of gases to improve the understanding and application of the concept in daily life.

\section{CONCLUSION}

The results of this study about the concept of gas kinetic theory, $30 \%$ of students were still at the LMMA level, $50 \%$ were at the MMMA level, and $20 \%$ were at the HMMA level. These results indicate that students' ability in mental modeling on average is still at the moderate level (LMMA). The identification of students' mental and MMA models is one of the references for teachers and other researchers in relation to physics, especially the concept of the kinetic theory of gases. These results can lead teachers to facilitate students to the correct mental model because students' mental model can be changed by communicative interactions built in the learning process [20]. Furthermore, by knowing how students' mental models and the ability to change mental models, the success of the learning process can be easily directed, because students do not feel inadequate in adapting to new concepts [21].

\section{AUTHORS' CONTRIBUTIONS}

All authors conceived and designed this study. All authors contributed to the process of revising the manuscript, and in the end, all authors have approved the final version of this manuscript.

\section{REFERENCES}

[1] Kusaeri, A. Ridho, Learning outcome of mathematics and science: Features of Indonesian madrasah students, in: Jurnal Penelitian dan Evaluasi Pendidikan, vol. 23, no. 1, June 2019, pp. 95-105.

[2] R.M.D. Guido, Attitude and motivation towards learning physics, in: International Journal of Engineering Research \& Technology, vol. 2 issue 11, November 2013, pp. 2087-2093.

[3] Jufrida, W. Kurniawan, Astalini, Darmaji, D.A. Kurniawan, W.A. Maya, Students' attitude and motivation in mathematical physics. Department of Physics Education, in: Indonesia International Journal of Evaluation and Research in Education (IJERE), vol. 8, no. 3, September 2019, pp. 401408. DOI: 10.11591/ijere.v8i3.20253

[4] J.W. Lin, M.H. Yen, J.C. Liang, M.H. Chiu, C.J. Guo, Examining the factors that influence students' science learning processes and their learning outcomes: 30 years of conceptual change research, in: Eurasia Journal of Mathematics, Science \& Technology Education, 2016, pp. 2617-2646. DOI: 10.12973/eurasia.2016.000600a

[5] Suparlan, Constructivism theory in learning, in: Jurnal Ke-Islaman dan Ilmu Pendidikan, vol. 1, no. 2, July 2019, pp. 79-88.

[6] Permendiknas No. 22 tahun 2006 tentang Standar Isi untuk Satuan Pendidikan Dasar dan Menengah, Kementerian Pendidikan Republik Indonesia.

[7] R. Bhalwankar, J. Treur, Modelling the development of internal mental models by an adaptive network model, in: Procedia Computer Science vol. 190, 2021, pp. 90-101.

[8] E.F. Redish, Implication of cognitive studies for teaching physics, in: American Association of Physics Teachers, 1994, pp. 796-803.

[9] L.A.R. Laliyo, Model mental siswa dalam memahami perubahan wujud zat, in: Jurnal Penelitian dan Pendidikan, vol. 08 (10), 2011, pp. $1-12$.

[10] Wiji, Pengembangan desain perkuliahan kimia sekolah berbasis model mental untuk meningkatkan pemahaman materi subyek mahasiswa calon guru kimia, Disertasi Sekolah Pasca Sarjana UPI, Bandung, 2014, Tidak Diterbitkan.

[11] Ozcan, Ozgur, C. Gercek, Student's mental models of light to explain the compton effect, social and behaviora sciences, 2015 , pp. $2195-2197$.

[12] C.Y. Wang, The role of mental-modelling ability, content knowledge, and mental models in general chemistry students' understanding about molecular polarity, Ph. D Dissertation, Columbia : University of Missouri, 2007.

[13] J.R. Fraenkel, N.E. Wallen, H.H. Hyun, How to design and evaluate research in education, McGrawHill Publishing Company, 2012.

[14] H. Haili, Problem solving based learning model with mutiple representation to improve student's mental modelling ability on physics, in: AIP Conference Proceeding, 2018.

[15] Supriyatman, Pengembangan program perkuliahan kelistrikan dan kemagnetan berbasis pemecahan masalah untuk memperbaiki model mental dan meningkatkan mental model ability mahasiswa calon guru fisika, Disertasi Sekolah Pascasarjana UPI, Bandung, 2016, Tidak Diterbitkan.

[16] I. Ramadhani, R. Tanjung, Identification of learning difficulties in junior high school physics in Langkat 
Regency, in: Indonesian Physics Education Research, vol. 1, no. 1, December 2020, pp. 53-60.

[17] H. Helma, D. Murni, Study of factors affecting student learning outcomes in Real Analysis lectures during the Covid-19 pandemic, in: Journal of Physics: Conference Series 1742 (2021), pp. 1-6, DOI: 10.1088/1742-6596/1742/1/01203

[18] P. Haussler, L. Hoffmann, A curricular frame for physics education: Development, comparison with students' interests, and impact on students' achievement and self-concept, October 2000.

[19] Darmaji, R. Perdana, D.A. Kurniawan, A study relationship attitude toward physics, motivation, and character discipline students senior high school, in Indonesia, in: International Journal of Learning and Teaching, vol. 11, no.3, 2019, pp. 99-109.

[20] J.W. Lin, M.H. Chiu, Exploring the characteristics and diverse sources of students' mental models of acids and bases, in: International Journal of Science Education, 29(6), 2007, pp. 771-803.

[21] World Development Report Mind, Society, and Behavior, Thinking with Mental Models, 2015, pp. 62-75. 